\section{Inheritance of Resistance to Gummy Stem Blight in Watermelon}

\author{
Gabriele Gusmini, Luis A. Rivera-Burgos ${ }^{1}$, and Todd C. Wehner \\ Department of Horticultural Science, North Carolina State University, \\ Raleigh, NC 27695-7609
}

Additional index words. Stagonosporopsis cucurbitacearum, Citrullus lanatus, plant introduction, disease resistance

\begin{abstract}
Gummy stem blight (GSB), caused by three related species of Stagonosporopsis [Stagonosporopsis cucurbitacearum (syn. Didymella bryoniae), Stagonosporopsis citrulli, and Stagonosporopsis caricae], is a major disease of watermelon [Citrullus lanatus (Thunb.) Matsum. \& Nakai] in most production areas of the United States. We studied the inheritance of resistance to GSB using three PI accessions of watermelon. Four families of six progenies $\left(P_{r}, P_{s}, F_{1}, F_{2}, B_{1} P_{r}\right.$, and $\left.\mathbf{B C}_{1} P_{s}\right)$ were developed from four crosses of resistant $P I$ accessions by susceptible cultivars. Each family was tested in 2002 and 2003 in North Carolina under field and greenhouse conditions for resistance to GSB. Artificial inoculation was used to induce uniform and strong epidemics. The effect of the Mendelian gene for resistance, $d b$, was tested. Partial failure of the data to fit the singlegene inheritance suggested that resistance to GSB of PI 482283 and PI 526233 may be under the control of a more complex genetic system.
\end{abstract}

Gummy stem blight is a major disease of watermelon [C. lanatus (Thunb.) Matsum. \& Nakai]. It is caused by three genetically distinct Stagonosporopsis species, S. cucurbitacearum (syn. Didymella bryoniae), $S$. citrulli, and $S$. caricae (Stewart et al., 2015). The three species are pathogenic to cucurbits, but $S$. caricae also causes leaf spot and stem and fruit rot in papaya (Carica papaya) (Stewart et al., 2015). This disease was first observed in 1891 by Fautrey and Roumeguere in France on cucumber ( $\mathrm{Cucu}$ mis sativus L.) and in Delaware in watermelon (Chiu and Walker, 1949; Sherf and MacNab, 1986). In 1917, GSB was reported in the Southern United States, affecting watermelon fruit in Florida (Sherbakoff, 1917). Gummy stem blight remains an important limiting factor for watermelon production in Florida (Keinath, 1995; Power, 1992). Gummy stem blight on watermelon plants is evident as crown blight, stem cankers, and extensive defoliation, with symptoms observed on the cotyledons, hypocotyls, leaves, and fruit (Maynard and Hopkins, 1999). Stagonosporopsis cucurbitacearum is seedborne (Lee et al., 1984), airborne (van Steekelenburg, 1983), and soilborne (Bruton, 1998; Keinath, 1996).

Adequate control of GSB through fungicide applications (Keinath, 1995, 2000, 2016) and appropriate cultural practices (dos Santos et al., 2016; Rankin, 1954; Keinath,

Received for publication 22 May 2017. Accepted for publication 12 Sept. 2017

We thank Tammy L. Ellington for her assistance with plant production in the field and greenhouse and Gerald J. Holmes and Anthony P. Keinath for their advice on pathogen handling.

${ }^{1}$ Corresponding author. E-mail: lariver2@ncsu. edu.
1996) is difficult, particularly during rainfall when relative humidity remains high for extended times (Café-Filho et al., 2010). In addition, there is concern among pathologists and breeders for the development of resistance by $S$. cucurbitacearum to fungicides (Avenot et al., 2012; Kato et al., 1984; Keinath and Zitter, 1998; Li et al., 2016; Malathrakis and Vakalounakis, 1983; Miller et al., 1997; Thomas et al., 2012; van Steekelenburg, 1987). Resistance to GSB has received attention since the 1970 s as a possible alternative to chemical control (Lou et al., 2013; Norton et al., 1986, 1993, 1995).

Differences in GSB resistance among commercial cultivars of watermelon $(C$. lanatus) were reported, with 'Congo' the least susceptible, 'Fairfax' intermediate, and 'Charleston Gray' the most susceptible (Schenck, 1962). Resistance assays by controlled inoculation of watermelon plants using spore suspensions of $S$. cucurbitacearum identified PI 189225 and PI 271778 as the most resistant accessions available in the USDA-ARS watermelon germplasm collection (Sowell, 1975; Sowell and Pointer, 1962). In crosses with susceptible 'Charleston Gray', a single recessive gene $d b$ was determined to confer resistance in PI 189225 (Norton, 1979). Resistant watermelon cultivars were developed from two crosses ('Jubilee' $\times$ PI 271778 and 'Crimson Sweet' $\times$ PI 189225 ) by selecting diseaseresistant seedlings from backcrossed families that had a high yield of excellent quality fruit (Norton et al., 1986). 'AU-Jubilant', 'AU-Producer' (Norton et al., 1986), 'AUGolden Producer' (Norton et al., 1993), and 'AU-Sweet Scarlet' (Norton et al., 1995) were released, with moderate resistance to GSB. However, they were found less resistant to GSB than the resistant parents PI 189225 and PI 271778. To date, no cultivars of watermelon have been released that have a high level of resistance to natural epidemics of GSB.

The expanding watermelon industry in the southeastern United States and the increasing losses due to GSB outbreaks in the last decade led to a new set of studies for the use of genetic resistance to control GSB in watermelon (Gusmini et al., 2005; Li and Brewer, 2016). The watermelon breeding program at North Carolina State University developed an efficient screening method for testing watermelon germplasm (Gusmini and Wehner, 2002; Song et al., 2004), including systems for mass production of inoculum of $S$. cucurbitacearum for large field screening experiments (Gusmini et al., 2003), and a disease assessment scale for rating foliar and stem lesions (Gusmini et al., 2002). Available PI accessions (totaling 1274) from the USDA-ARS watermelon germplasm collection, along with 51 adapted cultivars, were tested to identify new genetic sources of resistance to GSB (Gusmini et al., 2005). A total of 59 new accessions were identified that had resistance to GSB as good as or better than PI 189225 and PI 271778 at the field and greenhouse tests. Two of the best were PI 482283 and PI 526233.

The objective of this study was to determine the inheritance of resistance to GSB in watermelon accessions PI 482283 and PI 526233, along with the previously identified accession PI 189225. Because of the unsuccessful breeding history for this trait, we hypothesize that resistance to GSB is due to a more complex mode of inheritance, which will be tested by validating the monogenic inheritance of $d b$ gene in PI 482283 and PI 526233.

\section{Material and Methods}

Plant material. We used four families developed from the four crosses PI 189225 $\times$ 'NH Midget', PI $482283 \times$ 'NH Midget', PI $482283 \times$ 'Calhoun Gray', and PI $526233 \times$ 'Allsweet'. 'NH Midget', 'Calhoun Gray', 'Allsweet', and PI 526233 were C. lanatus subsp. vulgaris (Chomicki and Renner, 2015). PI 189225 and PI 482283 were Citrullus amarus (Chomicki and Renner, 2015). PI 189225, PI 482283, and PI 526233 were used as resistant parents, and 'NH Midget', 'Calhoun Gray', and 'Allsweet' were used as susceptible parents (Gusmini et al., 2005). The cultivars were obtained from commercial seed stocks, and the PI accessions were obtained from the Southern Regional Plant Introduction Station at Griffin, GA. For each family, we developed six progenies $\left(\mathrm{P}_{\mathrm{r}}, \mathrm{P}_{\mathrm{s}}\right.$, $\mathrm{F}_{1}, \mathrm{~F}_{2}, \mathrm{BC}_{1} \mathrm{P}_{\mathrm{r}}$, and $\mathrm{BC}_{1} \mathrm{P}_{\mathrm{s}}$ ) using greenhouses at North Carolina State University in Raleigh, NC.

Plating and management. In the greenhouse, temperatures averaged 23 to $43{ }^{\circ} \mathrm{C}$ (0800-2000 HR) and 12 to $24{ }^{\circ} \mathrm{C}(2000-0800$ $\mathrm{HR})$ when the assays were performed. We seeded directly in plastic pots $(100 \times 100 \mathrm{~mm}$ size, $600 \mathrm{~mL}$ volume) filled with a soilless mix (Canadian sphagnum peatmoss, perlite, 
vermiculite, processed pine bark). We planted two seeds per pot and thinned to one to ensure a uniform experiment. In the field, seeds were sown on raised, shaped beds on $3.1 \mathrm{~m}$ centers in single hills, $1.2 \mathrm{~m}$ apart. Border rows of the susceptible 'Charleston Gray' and 'Calhoun Gray' were planted around each test.

We conducted our tests in greenhouses at North Carolina State University in Raleigh, $\mathrm{NC}$, and in the field at the Horticultural Crops Research Station at Clinton, NC. The two families PI $526233 \times$ 'Allsweet' and PI $482283 \times$ 'Calhoun Gray' were tested in 2002, whereas the other two were tested in 2003.

Inoculum preparation. Originally, the isolate of S. cucurbitacearum was obtained from diseased cucumber tissues harvested from naturally infected plants in Charleston, SC, in 1998. In the fall of 2001, we reisolated $S$. cucurbitacearum from watermelon plants that were artificially inoculated with the isolate from South Carolina and developed a new stock of inoculum from single spores. Pycnidia were identified with a dissecting microscope $(20 \times)$ and transferred to petri plates containing potato dextrose agar (PDA) $(25 \mathrm{~mL} /$ petri plate). Isolates were selected from the first subculture on PDA based on macroscopic observations: colonies dark in color and showing concentric circles of growth were kept and transferred to fresh PDA. Cultures that did not appear contaminated by other fungi or bacteria were transferred to a medium containing 25\% PDA to stimulate abundant sporulation. Finally, we observed pycnidia/pseudothecia and spores to verify that their shape and size matched those of $S$. cucurbitacearum as published (Zitter et al., 1996). For long-term storage (Dhingra and Sinclair, 1995), we transferred the fungus onto sterile filter paper (Whatman $\# 2,70 \mathrm{~mm}$ diameter), subcultured the fungus for 2-4 weeks, dehydrated the filter paper disk and the mycelium for $12-16 \mathrm{~h}$ at room temperatures $\left(24 \pm 3{ }^{\circ} \mathrm{C}\right)$ under a sterile laminar flow hood, cut the filter paper into squares $(5 \times 5 \mathrm{~mm})$, and stored them in sterile test tubes in a refrigerator $\left(3 \pm 1{ }^{\circ} \mathrm{C}\right)$ in the dark.

Cultures of $S$. cucurbitacearum were grown in Nalgene autoclavable pans $(420 \times$ $340 \times 120 \mathrm{~mm})$ containing $1000 \mathrm{~mL}$ of $50 \%$ PDA (Gusmini et al., 2003) before inoculation. We incubated the Nalgene pans for $2-4$ weeks at $24 \pm 2{ }^{\circ} \mathrm{C}$ under alternating periods of $12 \mathrm{~h}$ of fluorescent light $\left(40-90 \mu \mathrm{mol} \cdot \mathrm{m}^{-2} \cdot \mathrm{s}^{-1}\right.$ photosynthetic photon flux density) and $12 \mathrm{~h}$ of darkness until pycnidia formed. For all inoculations, we prepared a spore suspension by flooding the culture plates with 10 $\mathrm{mL}$ of sterile, distilled water, and gently scraping the surface of the agar with an Lshaped sterile glass-rod to remove the spores from the mycelia. We filtered the liquid from each pan through four layers of sterile cheesecloth to remove dislodged agar and some mycelia. We measured spore concentration with a hemocytometer and adjusted to a concentration of $5 \times 10^{5}$ spores $/ \mathrm{mL}$ by adding deionized water. Tween $20\left(0.06 \mathrm{~g} \cdot \mathrm{L}^{-1}\right)$ was added to the inoculum to keep the spores well dispersed in the inoculum solution (Song et al., 2004).

Inoculation. In the greenhouse, we inoculated plants at the second-true-leaf stage ( $\approx 2$ weeks after planting), after damaging the trichomes on the leaf surface by brushing the plants with a wooden stake $200 \mathrm{~mm}$ long and $20 \mathrm{~mm}$ wide. The inoculum was delivered using a hand-pumped spray bottle. Immediately after inoculation, we moved the plants into a humidity chamber made of clear polyethylene on the sides and top. The top was kept open during the summer and closed during the winter to keep the internal temperature close to $24{ }^{\circ} \mathrm{C}$, the optimum for $S$. cucurbitacearum. We used humidifiers in the chamber running continuously for the treatment time ( $1 \mathrm{~d}$ before inoculation through $3 \mathrm{~d}$ after inoculation) to keep the relative humidity close to $100 \%$ day and night. Plants were watered daily using overhead sprinklers when humidifiers were not being used.

In the field, we inoculated plants when they reached the fourth-true-leaf stage $(\approx 4$ weeks after planting), after overhead irrigation of about $12 \mathrm{~mm}$ of water during the two previous days to promote guttation on the day of inoculation, and damaging the trichomes on the leaf surface at each time before the inoculum was delivered by brushing the plants with a wooden stake $200 \mathrm{~mm}$ long and $20 \mathrm{~mm}$ wide mounted on an aluminum handle $600 \mathrm{~mm}$ long (Lou et al., 2013; Song et al., 2004). Plants were inoculated at least two times at 2 -wk intervals by spraying the inoculum onto all upper leaf surfaces. We delivered the inoculum as a fine mist using a backpack-sprayer operated at a pressure of $200-275 \mathrm{kPa}(30-40 \mathrm{psi})$. In the late afternoon of the day of inoculation, we irrigated with $\approx 12 \mathrm{~mm}$ of water to promote disease development with high relative humidity at night.

Data collection. Plants were rated $\approx 5$ weeks after planting $(\approx 3$ weeks after inoculation) in the greenhouse, and when symptoms appeared on the leaves and stems of the susceptible checks in the field $(\approx 7$ weeks after planting $=\approx 1$ week after the second inoculation). We adopted an ordinal disease assessment scale (Gusmini et al., 2002), with $0=$ no disease; $1=$ yellowing on leaves (a trace of disease only); $2-4=$ symptoms on leaves only; $5=$ some leaves dead, no symptoms on stem; 6-8 = symptoms on leaves and stems; $9=$ plant dead. Plants with a disease rating of 6 or greater had lesions on the stem, thus being prone to death from subsequent development of the disease. Plants with a disease rating of 5 or less had lesions only on the leaves. Leaf ratings are important because plant yield and survival are affected by leaf area, which is reduced by severe disease outbreaks. Stem ratings are important because large, localized lesions can kill the plant, especially if located near the crown (base) of the plant.

Statistical analysis. We tested the validity of the monogenic inheritance of the $d b$ gene, described by Norton (1979), after classifying each plant as susceptible or resistant based on their rank relative to the mean value of the disease assessment scale adopted (4.5). Plants with a disease rating $>4.5$ were considered susceptible and plants with a disease rating $<4.5$ were considered resistant (Gusmini et al., 2002, 2005). We performed segregation analysis and the chi-square goodness-of-fit tests $(P<0.05)$ for each $\mathrm{F}_{2}$ and $\mathrm{BC}_{1} \mathrm{P}_{\mathrm{r}}$ progeny with the SAS-STAT statistical package (SAS Institute, Cary, NC) and the SASGENE 1.2 program (Liu et al., 1997).

Yate's correction was used for those chisquare tests where counts were below five for any class in the ratio. However, there was no difference in the conclusion, so we presented the data without the correction to avoid the tendency of Yate's to overcorrect (Conover, 1974; Haviland, 1990).

\section{Results}

In our study, several observed segregation ratios for resistance to GSB in watermelon significantly deviated from the expected monogenic inheritance ratios, in both field and greenhouse tests (Table 1). The field and greenhouse tests appeared to be equally useful and mostly consistent in their classification of the resistant and susceptible parent lines. However, there was a combination of environmental variation for disease development and genotype $\times$ environment interaction for GSB resistance and perhaps escapes (from inoculation).

In PI $189225 \times$ 'NH Midget', $\mathrm{F}_{2}$ plants in the field test segregated 74:36 (susceptible: resistant) (Table 1). In this case, the chisquare test would be favorable to the single gene hypothesis except for the small $P$ value. Furthermore, the $\mathrm{F}_{2}$ greenhouse test did not indicate the validity of the single gene hypothesis suggested by the $F_{2}$ segregation ratio in the field. Similarly, the segregation ratios of $\mathrm{BC}_{1} \mathrm{P}_{\mathrm{r}}$ plants in the field and greenhouse significantly deviated from the expected ratios (Table 1). Thus, we rejected the hypothesis of a single gene controlling resistance to GSB, as previously reported by Norton in PI 189225.

In PI $482283 \times$ 'NH Midget', both field and greenhouse $F_{2}$ segregation ratio chisquare tests reject the null hypothesis of a single gene controlling the expression of resistance to GSB (Table 1). Similarly, greenhouse $\mathrm{BC}_{1} \mathrm{P}_{\mathrm{r}}$ segregation ratio chisquare test rejects the null hypothesis of resistance being controlled by a single gene, contributed by PI 482283 (Table 1).

In PI $482283 \times$ 'Calhoun Gray', field $\mathrm{F}_{2}$ and $\mathrm{BC}_{1} \mathrm{P}_{\mathrm{r}}$ segregation ratio chi-square tests failed to reject the null hypothesis of resistance being controlled by a single gene (Table 1). However, the $F_{1}$ progeny segregated close to $1: 1$, thus casting doubts on the validity of the single gene hypothesis. Furthermore, also in this cross, the greenhouse tests did not validate the segregation ratios recorded in the field. The $\mathrm{F}_{2}$ and $\mathrm{BC}_{1} \mathrm{P}_{\mathrm{r}}$ segregation ratio 
Table 1. Single locus chi-square goodness-of-fit-test $(P<0.05)$ for resistance to gummy stem blight $(\mathrm{GSB})$ in watermelon. ${ }^{\mathrm{z}}$

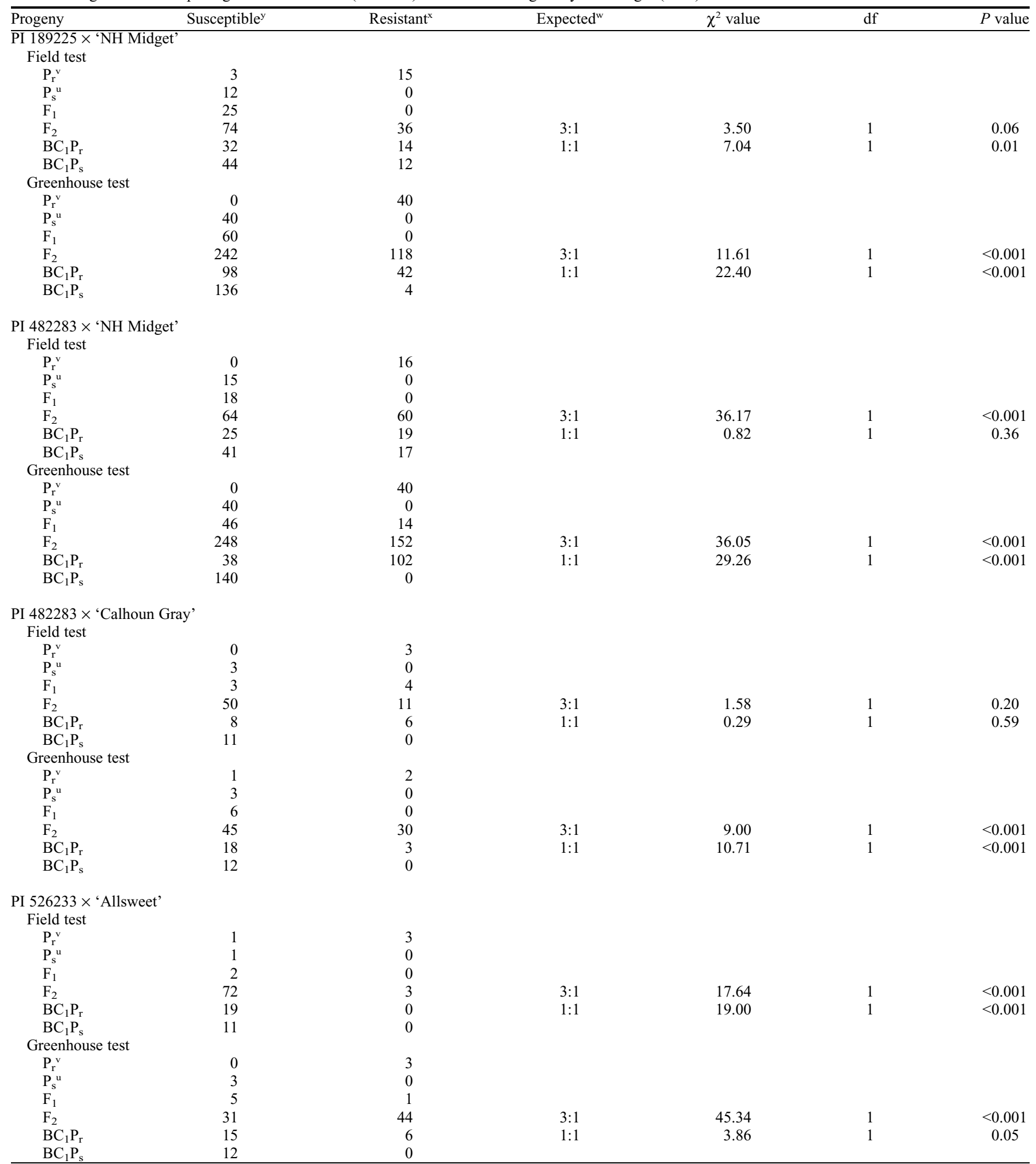

${ }_{\mathrm{z}}$ Data are ratings from four families of resistant PI accessions by susceptible cultivars of $C$. lanatus subsp. vulgaris. Disease assessment scale adopted for evaluating watermelon for resistance to GSB: $0=$ no disease; $1=$ yellowing on leaves (suspect of disease only); $2-4=$ symptoms on leaves only; $5=$ some leaves dead, no symptoms on stem; $6-8=$ symptoms on leaves and stems; $9=$ plant dead.

${ }^{\mathrm{y}}$ Susceptible plants had a disease rating $>4.5$.

${ }^{\mathrm{x}}$ Resistant plants had a disease rating $<4.5$.

${ }^{\mathrm{w}}$ Expected was the hypothesized segregation ratio for single-gene inheritance for each segregating progeny.

${ }^{\mathrm{v}} \mathrm{P}_{\mathrm{r}}$ was the hypothetic carrier of the recessive gene $(d b d b)$.

${ }^{\mathrm{u}} \mathrm{P}_{\mathrm{s}}$ was the hypothetic carrier of the dominant gene $(D b D b)$.

chi-square tests reject the null hypothesis of resistance being controlled by a single gene (Table 1).
In PI $526233 \times$ ×Allsweet', both field and greenhouse $F_{2}$ segregation ratio chi-square tests reject the null hypothesis of a single gene controlling the expression of resistance to GSB (Table 1). Also in this cross, field $\mathrm{BC}_{1}$ $P_{r}$ segregation ratio chi-square test reject the 
null hypothesis of resistance being controlled by a single gene, in this case, contributed by PI 526233. Although greenhouse $\mathrm{BC}_{1} \mathrm{P}_{\mathrm{r}}$ segregation ratio chi-square test failed to reject the null hypothesis of resistance being controlled by a single gene, the small $P$ value did not support validity (Table 1 ).

In Fig. 1, the distribution of our $\mathrm{F}_{2}$ data displayed continuous variation and deviated from the expected bell-shaped (normal) distribution. This distribution pattern suggests the presence of one or more resistant genes segregating in the progenies.

\section{Discussion}

Gummy stem blight has shown significant variability for resistance in cucurbits (Boyhan et al., 1994; Gusmini et al., 2005; Wehner and Shetty, 2000). For example, plant-to-plant variability in four replications of two plants each was 4-8 for 'Charleston Gray' compared with a 2-4 rating for PI 482276 on a 0 to 9 scale (Gusmini et al., 2005). Thus, the resistant PI accession was not more heterogeneous than the pure-line cultivar. In addition, the test for GSB resistance has variation from plant to plant and rep to rep of 2-4 rating units. Observed variability of GSB outbreaks may be the results of genetic or environmental effects (Wehner and Amand, 1993). These effects can modify pathogen aggressiveness, causing differences over years, and between field and greenhouse tests (Gusmini and Wehner, 2002; Stewart et al., 2015). Recently, genetically distinct species have been reported as causal agents of GSB, suggesting that variability of resistance to GSB across years and environments (e.g., greenhouse and field) may be due to interactions of environment with fungal species (Brewer et al., 2015; Keinath, 2014; Stewart et al., 2015).

Resistance to GSB in watermelon has been previously described as dependent solely on the inheritance of the recessive gene $d b$ from PI 189225 (Norton, 1979). Watermelon cultivars have been improved by introgression of the $d b$ gene, but the cultivars were less resistant than the resistant parent accessions in the field. In addition, PI 189225 was identified as a source of resistance to anthracnose (Colletotricum obiculare) race 2 (Sowell at al., 1980). Both $C$. obiculare and $S$. cucurbitacearum were reported as prevalent pathogens, occupying different niches in the plant canopy during field evaluations (Peterson and Campbell, 2002). Interestingly, similarities in the symptomatology of these pathogens could lead to misreading visual evaluations during field outbreaks (Boyhan et al., 1994; Gusmini et al., 2005). In addition, the lack of progress for resistance to GSB in the development of new cultivars could be explained partially by the confounded epidemics of several pathogens during field evaluations (Peterson and Campbell, 2002; Rankin, 1954).

A wide array of testing methods for resistance to GSB have been deployed by breeders during the last three decades to follow the inheritance of the $d b$ gene in their populations, and the one adopted in this study was demonstrated to be the most effective of the methods tried (Gusmini and Wehner,
PI 189225 × 'NH Midget'

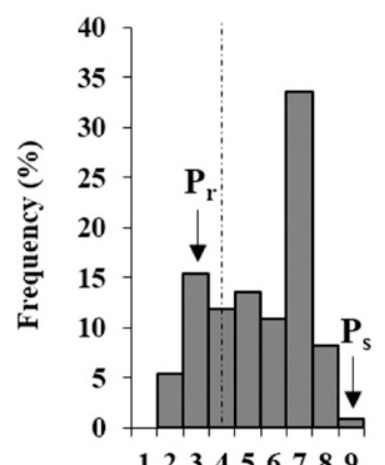

Field

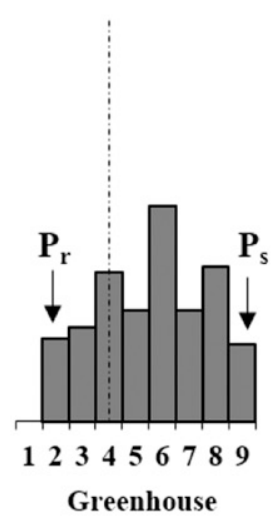

Greenhouse

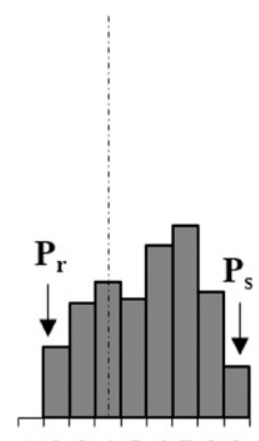

123456789

Pooled

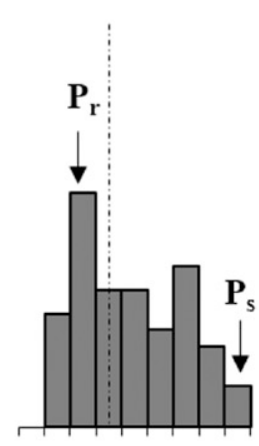

123456789 Field
PI 482283 × 'NH Midget'

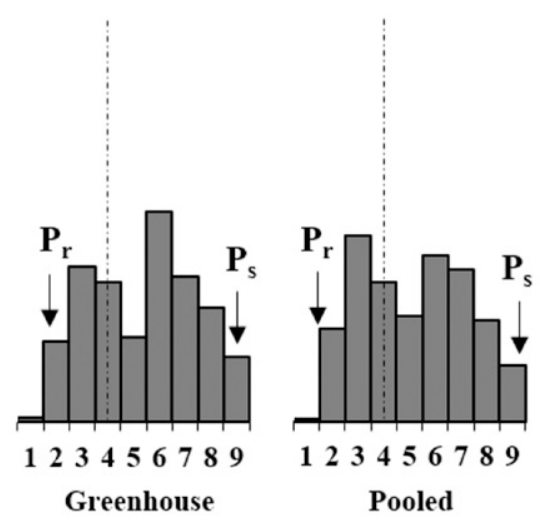

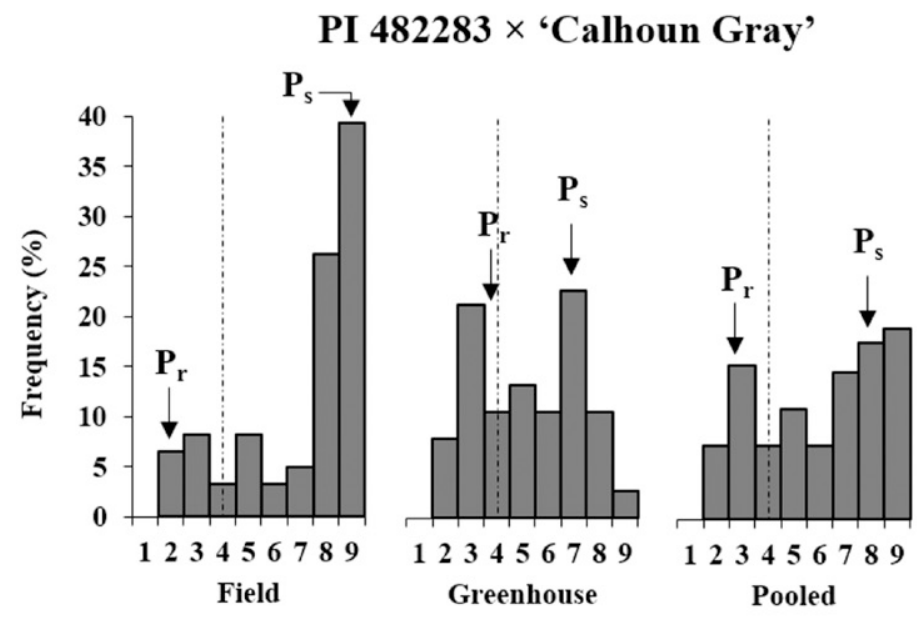

Gummy Stem Blight Rating

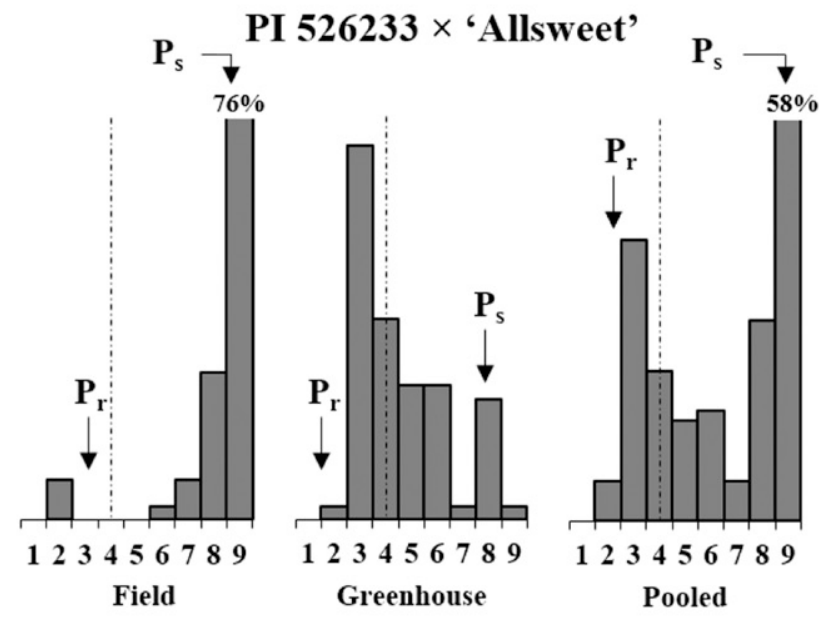

Gummy Stem Blight Rating

Fig. 1. Frequency distribution plots of $\mathrm{F}_{2}$ data for the four watermelon families (resistant PI accessions by susceptible cultivars of $C$. lanatus subsp. vulgaris) screened for resistance to gummy stem blight (GSB) in greenhouse and field tests in North Carolina (2002-03). Disease assessment scale adopted for the screening: $0=$ no disease; 1 = yellowing on leaves (suspect of disease only); $2-4=$ symptoms on leaves only; $5=$ some leaves dead, no symptoms on stem; 6-8 = symptoms on leaves and stems; $9=$ plant dead. $\mathrm{P}_{\mathrm{r}}$ and $\mathrm{P}_{\mathrm{S}}$ indicate GSB ratings of the resistant and the susceptible parents, respectively. The dotted lines indicate the mean value of the disease assessment scale (4.5). 
2002; Song et al., 2002, 2004). In those studies, the most resistant PI accession had a rating of 2.3 and the most susceptible had a rating of 6.3 , with a least significant difference $(0.05)$ of 0.4 . The robustness of the method used in this study $(0=$ no disease to $9=$ plant dead) relies on repeatability and replications within years and sites (Gusmini et al., 2005). However, this method was not able to prevent large differences between field and greenhouse tests. Also, there was variation among single plants of pure-line cultivars. For example, 'Charleston Gray' varied from a rating of 4 to a rating of 8 among seven plants evaluated (Gusmini et al., 2005).

Clear genetics ratios are fundamental to deduce the genetic basis of the dependence of one gene on another (Gusmini et al., 2004; Tetteh et al., 2013). Our study indicates that resistance to GSB in watermelon should not be attributed to a single recessive gene (i.e., $d b$ gene). The inconsistency between observed and expected ratios of several progenies in four different crosses suggests a more complex mode of inheritance for resistance to GSB, as well as a large environmental effect (greenhouse vs. field). The inconsistency of the observed ratios should be attributed, perhaps, to several loci interacting with each other, and also interacting with the environment (Kumar, 2009). In the greenhouse (a controlled environment), uniform conditions were created for plant and pathogen development. In the field (a variable environment), the evaluation of a high number of cultigens in each test required the use of large areas, increasing the environmental variation within the field per year and site. Across families, field goodness-of-fit-tests $\left(\mathrm{F}_{2}\right.$ and/or $\mathrm{BC}_{1} \mathrm{P}_{\mathrm{r}}$ ) showed inconsistency to fail to reject the single recessive gene hypothesis, suggesting possible confounding genetic and environmental effects for resistance to GSB. However, greenhouse goodness-of-fit-tests $\left(\mathrm{F}_{2}\right.$ and/or $\left.\mathrm{BC}_{1} \mathrm{P}_{\mathrm{r}}\right)$ consistently reject the single recessive gene hypothesis, suggesting a more complex mode of inheritance (Table 1). Indeed, if the resistance to GSB was solely due to the $d b$ gene, similar results should be expected in both greenhouse and field tests. Furthermore, in all four crosses, our $\mathrm{F}_{2}$ data showed a continuous and mixture distribution, arguably, influenced by genetic and non-genetic factors (Fig. 1). In the $F_{2}$, there were few plants with disease ratings similar to the resistant parent. That was the case for the $F_{2}$ of all crosses whether they were tested in the field or greenhouse. The distribution pattern also supported the presence of a more complex mode of inheritance, with large environmental effects, and modifier genes (Hopkins and Levi, 2008).

The lack of progress in breeding effectively for resistance to GSB is partially explained by our results. Our study showed that the observed segregation ratios varied from the expected segregation ratios in the greenhouse and field, giving evidence of large environmental effects and multiple loci involved in controlling resistance to GSB
(Gusmini and Wehner, 2005). We suggest that GSB-resistant cultivars be developed using more intercrossing of resistant with elite lines before selection is started to help break linkages and increase the chance of getting nonparental types (high resistance combined with high quality). Because of high trait variability, selection should be based on progeny rows $\left(\mathrm{F}_{3}\right)$ rather than single plants $\left(F_{2}\right)$. Finally, high environmental variability should be controlled by basing selection on data from multiple replications using both field and greenhouse tests.

\section{Literature Cited}

Avenot, H.F., A. Thomas, R.D. Gitaitis, D.B. Langston, Jr., and K.L. Stevenson. 2012. Molecular characterization of boscalid-and penthiopyrad-resistant isolates of Didymella bryoniae and assessment of their sensitivity to fluopyram. Pest Mgt. Sci. 68:645-651.

Boyhan, G., J.D. Norton, and B.R. Abrahams. 1994. Screening for resistance to anthracnose (race 2), gummy stem blight, and root knot nematode in watermelon germplasm. Cucurbit Genet. Coop. Rpt. 17:106-110.

Brewer, M.T., M. Rath, and H.X. Li. 2015. Genetic diversity and population structure of cucurbit gummy stem blight fungi based on microsatellite markers. Phytopathology 105:815-824.

Bruton, B.D. 1998. Soilborne diseases in Cucurbitaceae: Pathogen virulence and host resistance, p. 143-166. In: J.D. McCreight (ed.). Cucurbitaceae 98. ASHS Press, Alexandria, VA.

Café-Filho, A.C., G.R. Santos, and F.F. Laranjeira. 2010. Temporal and spatial dynamics of watermelon gummy stem blight epidemics. Eur. J. Plant Pathol. 128:473-482.

Chiu, W.F. and J.C. Walker. 1949. Physiology and pathogenicity of cucurbit black-rot fungus. J. Agr. Res. 78:589-615.

Chomicki, G. and S.S. Renner. 2015. Watermelon origin solved with molecular phylogenetics including Linnaean material: Another example of museomics. New Phytol. 205:526-532.

Conover, W. 1974. Some reasons for not using the Yates continuity correction on $2 \times 2$ contingency tables. J. Amer. Stat. Assoc. 69:374-376.

dos Santos, G.R., S.C.R. Sousa, F.C. Juliatti, A.C. Rodrigues, M.S. Dalcin, and A. Bonifácio. 2016. Control of gummy stem blight in watermelon through different management systems. Biosci. J. 32:371-377.

Dhingra, O.D. and J.B. Sinclair. 1995. Basic plant pathology methods, 2nd ed. CRC press, Boca Raton, FL.

Gusmini, G. and T.C. Wehner. 2002. Correlation of ratings for resistance to gummy stem blight in watermelon, p. 199-205. In: J.D. McCreight (ed.). Cucurbitaceae 2002. ASHS Press, Naples, FL.

Gusmini, G., T.C. Wehner, and G.J. Holmes. 2002. Disease assessment scales for seedling screening and detached leaf assay for gummy stem blight in watermelon. Rep. Cucurbit Genet. Coop. 25:36-40.

Gusmini, G., T.L. Ellington, and T.C. Wehner 2003. Mass production of gummy stem blight spores for resistance screening. Rep. Cucurbit Genet. Coop. 26:26-30.

Gusmini, G., T.C. Wehner, and R.L. Jarret. 2004. Inheritance of egusi seed type in watermelon. J. Hered. 95:268-270.

Gusmini, G., R. Song, and T.C. Wehner. 2005. New sources of resistance to gummy stem blight in watermelon. Crop Sci. 45:582-588.
Gusmini, G. and T.C. Wehner. 2005. Review of watermelon genetics for plant breeders. Rep. Cucurbit Genet. Coop. 28-29:52-61.

Haviland, M.G. 1990. Yates's correction for continuity and the analysis of $2 \times 2$ contingency tables. Stat. Med. 9:363-367.

Hopkins, D.L. and A. Levi. 2008. Progress in the development of Crimson Sweet-type watermelon breeding lines with resistance to Acidovorax avenae subsp. citrulli, p. 157-162. In: M. Pitrat (ed.). Cucurbitaceae 2008. Proceedings of the IXth EUCARPIA meeting on genetics and breeding of Cucurbitaceae, Avignon, France.

Kato, T., K. Suzuky, J. Takahashy, and K. Kamoshita. 1984. Negatively correlated cross-resistance between benzimidazole fungicides and methyl N-(3,5-dichlorophenyl) carbamate. J. Pestic. Sci. 9:489-495.

Keinath, A.P. 1995. Fungicide timing for optimum management of gummy stem blight epidemics on watermelon. Plant Dis. 79:354-358.

Keinath, A.P. 1996. Soil amendment with cabbage residue and crop rotation to reduce gummy stem blight and increase growth and yield of watermelon. Plant Dis. 80:564-570.

Keinath, A.P. 2000. Effect of protectant fungicide application schedules on gummy stem blight epidemics and marketable yield of watermelon. Plant Dis. 84:254-260.

Keinath, A.P. 2014. Reproduction of Didymella bryoniae on nine species of cucurbits under field conditions. Plant Dis. 98:1379-1386.

Keinath, A.P. 2016. Polyoxin D and other biopesticides reduce gummy stem blight but not anthracnose on melon seedlings. Plant Health Prog. 17:177-181.

Keinath, A.P. and T.A. Zitter. 1998. Resistance to benomyl and thiophanate-methyl in Didymella bryoniae from South Carolina and New York. Plant Dis. 82:479-484.

Kumar, R. 2009. Inheritance of fruit yield and other horticulturally important traits in watermelon [Citrullus lanatus (Thunb.) Matsum. \& Nakai]. Dissertation, North Carolina State University.

Lee, D.H., S.B. Mathur, and P. Neergaard. 1984. Detection and location of seed-borne inoculum of Didymella bryoniae and its transmission in seedlings of cucumber and pumpkin. Phytopathology 109:301-308.

Li, H.-X., K.L. Stevenson, and M.T. Brewer. 2016. Differences in sensitivity to a triazole fungicide among stagonosporopsis species causing gummy stem blight of cucurbits. Plant Dis. 100:1-7.

Li, H.-X. and M.T. Brewer. 2016. Spatial genetic structure and population dynamics of gummy stem blight fungi within and among watermelon fields in the southeastern United Sates. Phytopathology 106:900-908.

Liu, J.S., T.C. Wehner, and S.B. Donaghy. 1997. SASGENE: A SAS computer program for genetic analysis of gene segregation and linkage. J. Hered. 88:253-254.

Lou, L., H. Wang, C. Qian, J. Liu, Y. Bai, and J. Chen. 2013. Genetic mapping of gummy stem blight (Didymella bryoniae) resistance genes in Cucumis sativus-hystrix introgression lines. Euphytica 192:359-369.

Malathrakis, N.E. and K.J. Vakalounakis. 1983. Resistance to benzimidazole fungicides in the gummy stem blight pathogen Didymella bryoniae on cucurbits. Plant Pathol. 32:395-399.

Maynard, D.N. and D.L. Hopkins. 1999. Watermelon fruit disorders. HortTechnology 9:155161.

Miller, M.E., T. Isakeit, J.X. Zhang, and B.D. Bruton. 1997. Gummy stem blight and black 
rot of melons. In: M.E. Miller (ed.). Melon production system in South Texas, Annual Research report Texas A\&M University, Weslaco.

Norton, J.D. 1979. Inheritance of resistance to gummy stem blight caused by Didymella bryoniae in watermelon. HortScience 14:630-632.

Norton, J.D., R.D. Cosper, D.A. Smith, and K.S. Rymal. 1986. 'AU-Jubilant' and 'AU-Producer' watermelons. HortScience 21:1460-1461.

Norton, J.D., G. Boyhan, D.A. Smith, and B.R. Abrahams. 1993. 'AU-Golden Producer' watermelon. HortScience 28:681-682.

Norton, J.D., G. Boyhan, D.A. Smith, and B.R. Abrahams. 1995. 'AU-Sweet Scarlet' watermelon. HortScience 30:393-394.

Peterson, P.D. and C.L. Campbell. 2002. Prevalence and ecological association of foliar pathogens of cucumber in North Carolina, 1996-1998. Plant Dis. 86:1094-1100.

Power, H.J. 1992. South Carolina 1991 vegetable statistics. South Carolina Agr. Expt. Sta. Bul.

Rankin, H.W. 1954. Effectiveness of seed treatment for controlling anthracnose and gummy stem blight of watermelon. Phytopathology 44:675-680.

Schenck, N.C. 1962. Mycosphaerella fruit rot of watermelon. Phytopathology 52:635-638.

Sherbakoff, C.C. 1917. Some important diseases of truck crops in Florida. Florida Agriculture Experimental Station Bulletin 139:269-273.
Sherf, A.F. and A.A. MacNab. 1986. Vegetable diseases and their control. 2nd ed. Wiley, New York.

Song, R., G. Gusmini, and T.C. Wehner. 2002. Screening the watermelon germplasm collection for resistance to gummy stem blight. Acta Hort. 637:63-68. (XXVI International Horticultural Congress - Advances in Vegetable Breeding).

Song, R., G. Gusmini, T.C. Wehner, A. Lebeda, and H.S. Paris. 2004. A summary of eleven preliminary studies of greenhouse and field testing methods for resistance to gummy stem blight in watermelon, p. 301-305. In: A. Lebeda and H.S. Paris (eds.). Proceedings of Cucurbitaceae 2004, the 8th EUCARPIA Meeting on Cucurbit Genetics and Breeding, Palacki University, Olomouc, Czech Republic.

Sowell, G. 1975. An additional source of resistance to gummy stem blight in watermelon. Plant Dis. Rep. 59:413-415.

Sowell, G., Jr., B.B. Rohodes, and J.D. Norton. 1980. New sources of resistance to watermelon anthracnose. HortScience 105:197-199.

Sowell, G. and G.R. Pointer. 1962. Gummy stem blight resistance in introduced watermelons. Plant Dis. Rep. 46:883-885.

Stewart, J.E., A.N. Turner, and M.T. Brewer. 2015. Evolutionary history and variation in host range of three Stagonosporopsis species causing gummy stem blight of cucurbits. Fungal Biol. 119:370-382.
Tetteh, A.Y., T.C. Wehner, and A.R. Davis. 2013. Inheritance of resistance to the new race of powdery mildew in watermelon. Crop Sci. 53:880-887.

Thomas, A., D.B. Langston, Jr., and K.L. Stevenson. 2012. Baseline sensitivity and cross-resistance to succinate-dehydrogenase-inhibiting and demethylation-inhibiting fungicides in Didymella bryoniae. Plant Dis. 96:979-984.

van Steekelenburg, N.A.M. 1983. Epidemiological aspects of Didymella bryoniae, the cause of stem and fruit rot of cucumber (Cucumis sativus). Neth. J. Plant Pathol. 89:75-86.

van Steekelenburg, N.A.M. 1987. Resistance to benzimidazole and dicarboximide fungicides in Botrytis cinerea and Didymella bryoniae in cucumbers in The Netherlands. Universiteit Gent. Faculteit van de Landbouwkundige en Toegepaste Biologische Wetenschappen 52:875-880.

Wehner, T.C. and P.C. Amand. 1993. Field tests for cucumber resistance to gummy stem blight in North Carolina. HortScience 28:327-329.

Wehner, T.C. and N.V. Shetty. 2000. Screening the cucumber germplasm for resistance to gummy stem blight in North Carolina field tests. HortScience 35:1132-1140.

Zitter, T.A., D.L. Hopkins, and C.E. Thomas. 1996. Compendium of cucurbit diseases. American Phytopathological Society Press, St. Paul, MN. 